(C) Кондаурова Г. Ю., Мазніченко М. А., 2017

Кондаурова Ганна Юріївна, Мазніченко Марія Анатоліївна

Національний медичний університет ім. О. О. Богомольця

\title{
МОЖЛИВІ ПРИЧИНИ ВІДСУТНОСТІ СТУДЕНТІВ-МЕДИКІВ IЗ ЗАРУБІЖНИХ КРАЇН 3 ВИСОКИМ РІВНЕМ ЕКОНОМІКИ В УКРАЇНI
}

Медищина - один з найпопулярніших серед напрямків отримання освіти за кордоном. В статті наведено деякі відмінності між системою вищої медичною освітою в Україні та в економічно розвинутими країнами, такими як Сполучені Штати Америки та Канада. А також виділено ряд факторів, які мають вплив на інтеграцію студента-медика в процес навчання у вищому навчальному закладі Украӥни.

Ключові слова: медицина, вища освіта, іноземні студенти.

Проблема, їі зв'язок із важливими науковими чи практичними завданнями. Серед напрямків отримання освіти за кордоном, медицина - один 3 найпопулярніших, саме тому конкуренція поміж абітурієнтів дуже висока. У ВУЗи медичного спрямування 3 високим рейтингом вступають кращі випускники зарубіжних приватних шкіл, більшість 3 яких розпочинає підготовку до вступу за рік-два до приймальної компанії.

Практикуючі лікарі такого рівня займають вищі соціальні ніші в таких країнах, як наприклад, США, i це обумовлює певну «обмежувальну-станову» політику Американської Медичної Асоціації, i, як наслідок, - дуже високі ціни медичних послуг і медичної освіти на американському ринку.

Аналіз публікацій (виділення невирішених проблем). У США і Канаді вартість навчання за фахом «Лікувальна справа» у багато разів перевищує вартість отримання спеціальності «фармація» або «стоматологія», що не справджується принциповими відмінностями в рівні витрат вузів і відрізняється від ситуації в країнах, що розвиваються і більшості держав Європи. Навіть не рейтингові «мало престижні» американські університети, які займають невисокі місця в національних рейтингах вузів, стягують плату за навчання на лікаря до 100 тисяч американських доларів в рік. Крім того, в США просто мала кількість медичних вищих навчальних закладів. Освітній шлях до медичної спеціальності для молодого американця триває набагато довше, ніж для молодого українця - в силу відмінностей в організації освіти. Отримання медичної освіти за 
кордоном стає в США та інших розвинених країнах все більш популярним. Серед студентів-медиків Канади за кордоном навчається кожен десятий $[1 ; 2]$. Навіть такі невеликі країни як Кіпр, Гренада i Ямайка навчають сотні студентів-медиків з США. Університети Чехії, Польщі, Угорщини, Румунії та Філіппін заробляють значні кошти за допомогою англомовних програм навчання студентів-медиків 3 розвинених країн. Медичні ж вузи України навчають англійською мовою громадян країн третього світу, в основному з Південної Азії і Африки.

У США, наприклад, вступити у медичний ВУЗ на «лікувальну справу» відразу після школи в принципі неможливо. Спочатку потрібно отримати бакалаврський ступінь 3 іншої дисципліни найчастіше студенти вважають за краще природно-наукові спеціальності типу хімія, біологія, фізика. Потім потрібно здати вступний іспит. Який саме - залежить від обраної спеціальності: DAT для дантистів, ОАТ для офтальмологів, МСАТ для остеопатії і т. д. У Великобританіі майбутні лікарі здають іспити BMAT (BioMedical Admissions Test) i UKCAT (UK Clinical Aptitude Test). Вибip іспиту диктується вибором вузу: наприклад, ВМАТ потрібен для вступу в University of Oxford, University of Cambridge, Imperial College London, a UKCAT - в King's College London, Durham University, Cardiff University тощо [1;2].

У США, Канаді та багатьох інших англомовних країнах вступити до Medical School (яка $є$ еквівалентом вищих медичних навчальних закладів) в такому ранньому віці, як в Україні, і при такому рівні попередньої освіті просто нереально. Справа в тому, що немедичні і загальноосвітні дисципліни, які складають за чинним законодавством значну частину навчального плану першого i другого курсів українських медичних ВУЗів, в Medical School не викладаються зовсім. Це відбувається тому, що Medical School в США - це професійна школа. Загальноуніверситетська освіта забезпечується не нею, а особливою ланкою, яка розміщується між повною середньою школою (яка в США дванадцятирічна) i вищим медичним університетом. Ця ланка відсутня в українській системі освіти. I називається вона - коледж («College») [2; 3].

Виклад основного матеріалу, обгрунтування результатів дослідження. Ряд непорозумінь виникає через те, що в Україні назвою «коледж» легально користуються багато середніх професійних навчальних закладів. Через це безліч вітчизняних студентів і навіть професіоналів вузівської системи знаходяться в помилковій впевненості, що американський College - це теж середній навчальний заклад, щось типу технікуму або медучилища (Medical College). Але фактично College в США - це вищий навчальний заклад, що виконує 


\section{Збірник наукових статей}

функції загально університетської освіти. Термін навчання в більшості таких коледжів - чотири роки, і після його закінчення вони присуджують ступінь бакалавра наук.

У медиків рівню бакалавр відповідає середня спеціальна медична освіта i кваліфікація фельдшера. Саме тому, фактично, українські бакалаври-медики - це випускники медичних училищ 3 дипломами фельдшерів [3].

Сформована практика передбачає, що кваліфікації фельдшера вітчизняний студент-медик досягає до четвертого курсу вищих медичних навчальних закладів. Це підтверджується наявністю в наших навчальних планах виробничої практики в якості помічника лікаря, до якої студент-медик якраз і допускається одразу після четвертого курсу. Крім того, лікувально-профілактичні установи приймають на роботу (з дозволу деканату) у вечірній час, за сумісництвом 3 навчанням, на посади середнього медперсоналу студентів, які закінчили не менше чотирьох курсів. В Україні майбутні стоматологи, лікувальники та педіатри - всі є студентами-медиками [3; 4]. В американській вузівській практиці термін Medical Students до стоматологів не застосовується. Більш того, повсякденним є термін Medical Doctors, який для американців не містить ніякої тавтології і перекладається не як «медичний лікар», а скоріше як «лікар - спеціальності лікувальна справа».

Справа в тому, що у нас традиційно домінує цілісний підхід до організму хворого, до хвороби і до самої медицині. Тому згідно чинного українського законодавства ряд медичних спеціальностей можна отримати в вітчизняних медичних вузах тільки на основі післядипломної спеціалізації, вже маючи, як мінімум, диплом лікаря загальної практики $[4 ; 5 ; 6]$.

У США і Канаді, а також деяких країнах Західної Європи i третього світу, в силу історичних обставин, зберігся дещо редукціоністичний підхід до питання розмежування лікарських спеціальностей i повноважень. Це і призвело, в свою чергу, до своєрідної системи ранньої спеціалізації і відокремлення деяких гілок медицини до статусу їх повного розмежування.

Таким чином, в США і Канаді, після вивчення базових і медикобіологічних дисциплін в коледжі його випускники, яким, як правило, не менше 22-23 років, вступають на чотирирічне навчання в Professional School. Це може бути Medical School (медичний факультет), після чого фахівець отримує М. D. і стає лікарем (лікувальна справа).

Навчаючись чотири роки в Dental School (стоматологічний факультет), можна отримати диплом i ступінь D. D. S. (Лікарястоматолога). Навчаючись чотири роки в School of Podiatry 
(подіатричний факультет - не плутати з педіатричним), випускник стає D.P.M. - дипломованим фахівцем 3 лікування хвороб нижніх кінцівок. D. Р. М. - важливий і повноправний елемент західної ринково-страхової системи охорони здоров'я. Його кваліфікація контролюється загальнонаціональним стандартом, і без роботи він не сидить. А ось педіатром в Західній Європі і в США, на відміну від України, можна стати тільки в рамках післядипломної спеціалізації, вже маючи М. D [2; 3].

Після чотирирічної програми School of Optometry можна стати O. D. i мати можливість лікувати виключно очні хвороби, притому ж тільки неінвазивно. Як наслідок цього, від випускника Medical School в США, на відміну від випускника вищих медичних навчальних закладів України, не можна вимагати вміння підібрати окуляри - це не його спеціальність. У той же час оптометрист в США - виключно університетська спеціальність.

У США загальна тривалість навчання після повної середньої школи за фахом «мануальна терапія» - 6-8 років, як і для лікаряспеціальності лікувальна справа. D. C. лікарі спеціалізуються на неінвазивних методах лікування хвороб спини та хребта, мають фундаментальну підготовку в цих розділах ортопедії і суміжних областях, вони добре орієнтовані в окремих частинах курсу внутрішніх хвороб, неврології, лабораторної та інструментальної діагностики, але їх навчання не містить хірургічних дисциплін і фармакології, i закон не дозволяє їм застосовувати інвазивні маніпуляції.

Коло застосовуваних ліків, фармакологічних засобів, які застосовує D. C. лікар, обмежене вузьким списком анальгетиків, вітамінів і мінеральних речовин. У той же час M. D. при даній системі не має глибокої підготовки в розділах, відведених для D. C., i, як правило, не лікує хвороби спини і хребта.

Після чотирирічного навчання в School of Osteopathy випускник отримує диплом D. O. і право лікувати пацієнтів з різними хворобами у відповідності до цієї своєрідної відокремленої доктрини, багато в чому альтернативної алопатичній медицині та мануальній терапії.

Для всіх перерахованих вище гілок медицини в США діє ізоморфна система державної сертифікації, ліцензування та контролю якості знань. Проте, повертаємось до основного питання - причин відсутності студентів-медиків 3 розвинених зарубіжних країн в Україні. Американським школярам думка про вступ до українського медичного ВУЗу просто не може прийти в голову, так як випускники середніх шкіл до медичних університетів, в американському розумінні цього слова, просто не вступають, а відповідного еквіваленту американського університетського коледжу чи школи базових медикобіологічних наук в Україні немає. 


\section{Збірник наукових статей}

Висновки, перспективи. Таким чином, основний контингент потенційних студентів могли б скласти зрілі фахівці, які отримують медичну освіту фактично як другу вищу з уже набутими ступенями бакалавра, магістра та/або доктора однієї з вузьких спеціальностей. Але тут бар'єром служить те, що українські ВУЗи в типовому випадку пропонують стандартну програму, що складається з річного вивчення української мови на підготовчому відділенні та шестирічного навчання разом зі вчорашніми школярами. Зрозуміло, що для фахівця-медика у віці 26-30 років або ще старше (12 років в школі +4 роки коледжу +4 роки вищої професійної школи + якийсь стаж роботи за фахом, що дозволив переконатися в необхідності перекваліфікації) - це неприйнятно. Крім того, еквівалент нашої ординатури - Clinical Residency - за кордоном набагато триваліший (три-п’ять років замість двох) і значно більш насичений як з боку навчального, так і $з$ фізичнопрактичного навантаження [7; 8].

\section{Література}

1. Ханикатт С. Г. Американский врач с российским дипломом личный опыт и некоторые сопоставления / С. Г. Ханикатт // Медицина. XXI век. - 2008. - № 9 (10). - С. 112-114.

2. Чурилов Л. П. Опыт междисциплинарной интеграции и применения инновационно-образовательных технологий / Л. П. Чурилов, Ю. И Строев, В. И. Утехин // Медицина. ХХІ век. 2008. - № 9 (10). - С. 28-37.

3. Закон України «Про вищу освіту» [Електронний ресурс]. Режим доступу : http://zakon2.rada.gov.ua/laws/show/1556-18. - Назва 3 титул. екрану.

4. Банчук М. В. Сучасні питання розвитку вищої медичної освіти та кадрового забезпечення галузі охорони здоров'я / М. В. Банчук, О. П. Волосовець, І. І. Фещенко, Т. І. Чернишенко // Медична освіта. - 2008. - № 2. - С. 7.

5. Свтух М. Б. Забезпечення якості вищої освіти - важлива умова інноваційного розвитку держави і суспільства / М. Б. Свтух, I. С. Волощук // Педагогіка і психологія. - 2008. - № 1. - С. 70-74.

6. Коваленко О. Е. Сучасні підходи до управління якістю підготовки фахівців у вищому навчальному закладі / О. Е. Коваленко // Теорія і практика управління соціальними системами: філософія, психологія, педагогіка, соціологія. - 2008. - № 2. - С. 65-71.

7. Маевская В. А. О медицинском образовании в России и за рубежом / В. А. Маевская, Л. П. Чурилов // Вестник МАПО. - 2002. T. 11. - № 4. - C. 2.

8. Зайчик А. Ш. Врач, пациент и общество. Медико-этическая проблема в истории / А. Ш. Зайчик, Л. П. Чурилов // Медицина. XXI век. - 2009. - № 1-2 (14-15). - С. 71-80. 
Анна Кондаурова, Мария Мазниченко. Возможные причины отсутствия студентов-медиков из зарубежных стран с высоким уровнем экономики в Украине.

Медицина - одно из самых популярных направлений в образовании за границей. В статье приведень некоторые отличия между системою высшего образования в Украине и экономически развитыми странами, такими как Соединенные Штаты Америки и Канады. A также вылелен ряд факторов, которые влияют на интеграцию студентамедика в процесс обучения в высшем учебном заведении Украиныл.

Ключевые слова: медицина, высшее образование, иностранные студенты.

Anna Kondaurova, Maria Maznichenko. Possible reasons for the absence of medical students from foreign countries with a high level of economy in Ukraine.

Medicine is one of the most popular destinations in education abroad. The article shows some differences between the higher education system in Ukraine and economically developed countries, such as the United States and Canada. Also, a number of factors have been identified that affect the integration of a medical student into the learning process in a higher educational institution in Ukraine.

Keywords: medicine, higher education, foreign students.

Стаття надійшла до редакційної колегії 24.05.2017

УДК [159.98:378.016]:101

(C) Костікова О. В., 2017

Костікова Ольга Володимирівна

Харківський національний педагогічний університет ім. Г. Сковороди

\section{ОСВІТНІ РЕСУРСИ ПСИХОДІАГНОСТИКИ: АСПЕКТИ ФІЛОСОФСЬКОГО ДОСВІДУ}

Проаналізовано інформативний потенціал $i$ затребуваність психодіагностичних досліджень в системі сучасної вищої освіти. Позначено ймовірний вплив філософії Г. С. Сковороди на становлення украйнської психодіагностики. Обтрунтовано конструктивність філософсько-психодіагностичної компетентності студентівпедагогів, як майбутніх фахівиів українсько-європейського освітнього простору.

Ключові слова: фахівець, психодіагностика, вища освіта, філософія.

Проблема, іiі зв'язок із важливими науковими чи практичними завданнями. Вимоги сучасності в спектрі удосконалення змісту вищої професійної освіти звертають увагу 